\title{
Digital technologies in retail: is there an impact on businesses?
}

\author{
Alena Borisova ${ }^{1}$, Ekaterina $_{\text {Borisova }}{ }^{2}$ Elene Kirichenko ${ }^{1}$, Ludmila $_{\text {Dmitrieva }}{ }^{1}$ \\ ${ }^{1}$ Novosibirsk State Technical University, Novosibirsk, Russia \\ ${ }^{2}$ Higher School of Economics, Moscow, Russia
}

\begin{abstract}
Increasing competition in the market leads to the search for tools to influence consumer choice. The dynamism of customers' requirements, their taste preferences and ways of communicating with suppliers is a source of continuous development companies. The digital business environment is formed under the influence of the intensity and speed of implementation of automated solutions in the company's activities and setting up a mechanism for interaction with stakeholders. There is a surge of interest in developing technological solutions based on digital technologies. Companies that use such solutions evaluate the effectiveness of their investments. Investment activity is based on maintaining a balance between the impact of technology on operational activities in the present and ensuring the preservation of market positions in the strategic perspective. There is a research hypothesis about the impact of technology implementation in the company's activities on its performance in the market. Diagnostics was carried out on the example of the leaders of the Russian retail market. Technologies that were tested in the company have been identified, the dynamics of business indicators have been studied, and expert assessments of an analytical company's specialist on the factors influencing the introduction of technologies have been analyzed.
\end{abstract}

\section{Introduction}

The development and timely implementation of information technologies is a key condition for maintaining the competitiveness of companies [5]. Digitalization of activities an important condition for the formation of a stable competitive advantage of the company.

Experts recognize that digitalization is the basis for a leadership position in a competitive market $[12,16]$. Therefore, over the past period, the legal regulation of the 
use of digital and automated technologies and tools has changed significantly. Analytical and research works of recent years also record the tools of reflection and conclusions on the success of technology application [1]; the arsenal of diagnostic tools is gradually expanding and instrumental solutions for planning, monitoring and forecasting, including predictive analytics, are being developed on their basis [17]. The need to continue studying the practices of implementing information technologies in the operational activities of companies and developing methodological tools for knowledge.

It is obvious that in the future, the trend towards digitalization of all human life processes will increase.

Updating new client requests and their satisfaction through the introduction of technologies has also led to research activity. The number of works devoted to the analysis of changes in consumer preferences is increasing [7]; as well as reviews of technological solutions for automation and digitalization of business processes $[14 ; 15]$; and understanding and evaluating the impact of technological changes in the practice of companies [10].

Leading competitive positions in the market for companies that use new technologies ahead of the curve. At the same time implementation of digital technologies is an expensive process, accompanied by a complex of risks. Therefore, companies are forced to maintain a balance of interests and opportunities for operational functioning and strategic development.

A review of research approaches to the implementation of information technologies [11] shows a shift in interest in innovation solutions. However, the request for a business management system that "thinks in terms of numbers (costs and benefits) is different. Management decisions require a systematic vision of the impact of information technology on business processes. Therefore, the business request is focused on eliminating the technology-focused approach to the introduction of information technologies and building a comprehensive system for evaluating the feasibility of their introduction into the business.

The research literature has not yet formed a unified view of the tools for assessing the impact of information technology implementation on the company's business results. There are developments on identifying a set of influence factors that determine the success of implementation [4], assessing the impact on the estimated value of companies [18]. From an economic point of view, the main task is to create additional value for both consumers and companies. Therefore, in this article, the authors are focused on testing the idea of a comprehensive approach to assessing the impact of the introduction of new information technologies on the company's performance.

The choice is justified by the following provisions. The differentiation of companies is recorded as they implement information technologies in their activities. There are estimates of industry development based on modern means of communication [2;15]. Probably, the depth of penetration and the degree of prevalence is dictated by changes in consumer demand and preferences, as well as the resulting effect. The retail sector is extremely dynamically developing, characterized by a deep degree and frequency of contact with consumer demand and a significant amount of investment [19].

Analysis of publications that focus research on the retail market, revealed: theoretical generalizations and tools are mainly presented in the works of foreign authors, research by Russian authors is mainly focused on analytical reviews of research companies. This 
is why Russian companies use either foreign methods or develop their own ones. The domestic market is characterized by the approach to the stage of rapid growth, which is complicated by the position of "catching up". So, the analysis of established practices in previous years is, in our opinion, an acceptable way to obtain data for the solution of the proposed goal.

The idea of the study is subordinate to the goal and contains a set of steps: first, we will assess the state of the domestic retail market, second, we will make an overview of modern digital solutions implemented in the retail sector and identify their functional purposes; third, we will assess the impact of information technologies in the activities of "X5 Group" and "Magnit" companies on the performance of their activities by analyzing secondary data and expert interviews; and finally, we will summarize the results of the review of market development, technologies and measures of their influence.

\section{Retail market in Russia: state and dynamics of performance}

In the retail market, there are common categories of sales products: durable goods; items of daily consumption; food and art. The article focuses on the market of consumer goods, which is characterized by a large turnover of goods, a short life cycle, ease of replacement, seasonality of demand and a relatively low price category. The sale of consumer goods is carried out through a greater variety of channels and forms of interaction with the consumer. The consumer of this group of products is also endowed with specific features that affect the choice and preferences. The features of the market and customer characteristics determine the requirements for channels, forms and means of interaction.

The domestic FMCG market has dynamics of annual growth in the range from 5 to $10 \%$ [8]. The share of leading companies that make up the TOP-10 (X5 Retail Group, Magnit, DKBR, Lenta, Auchan, METRO, O'KEY) accounts for more than 33\% of the market. The list of Top-10 is stable with minor fluctuations in the championship. However, it tends to change the composition. Therefore, according to the last year results, the candidate for inclusion in the leadership list is "Maria-RA".

Assessment of the domestic retail market shows that none of the companies occupies a dominant position in the market and cannot dictate the terms of interaction with the consumer, according to the price and assortment policy of the rest. Our chosen target is X5, which occupies $11.5 \%$ of the industry (2019) and actively uses offensive strategies to increase its share. We can conclude that the company adheres to the strategy of "leadership contention". And other companies in the industry competitors company X5, DKBR, Lenta, Auchan, METRO and O'KEY also use this strategy.

A study of the company's key indicators (revenue, gross profit, number of stores, EBITDA, and company shares) over the past 3 years has led to the conclusion that the company is slowly but continuously increasing these indicators. We can assume that one of the reasons for this growth is the fact that, starting in 2017 , the company is actively implementing modern technologies in its business processes.

Perhaps (research hypothesis) the introduction of technologies provides «X5» with a leadership claim. Analysis of the experience of "Magnit" and "Lenta" suggests that the rapid growth of competitive positions in the market is based on the introduction of technologies. 
Regular dynamics of sales channels are recorded: hard discounters are growing rapidly (sales growth in 2019 by $49.1 \%$ ), e-commerce $(43.3 \%$ ) and specialty grocery stores $(27 \%)$ [8]. Over the past five years, according to Nielsen [3], the number of hypermarkets has decreased by almost a third. Experts associate this tend with a steady growth in the number of consumers of FMCG-market products via the Internet.

Consumer demand is also under change: the daily purchase of products becomes more frequent [13]; the choice in favor of ready meals and shift the products under the brand name "healthy food". At the same time, a consumer, generation $\mathrm{Y}$ and $\mathrm{Z}$, values speed, wide choice, and personalization. Domestic companies that were the first to take into account changes in consumer choice and introduced technologies to satisfy it, increased the volume of goods in turnover by $15 \%$ (2019) [4].

At the same time, the low rate of economic development of the country can be called a limiting factor in the development of digital technologies in trade. Thus, by the end of 2019 , the growth rate of the gross domestic product is significantly reduced to $1.3 \%$ (in $2018-2.3 \%$ ) against the background of the continuing level of inflation. The demographic situation is also negative. The population of Russia is shrinking every year. At the same time, there is a shift in the share of the population by age structure: the share of the economically active population is significantly reduced. The problem is compounded by another limiting and constraining factor: regional development features, which determine the differentiation of consumers by preferences, channels of interaction, and heterogeneity of infrastructure and personnel provision in the regions.

Thus, despite the active development of the retail sector and the accumulated practice of using information technologies, there are significant restrictions on their wide distribution and implementation.

\section{Information technologies in retail: tasks to be solved and advantages}

Information technology combines a set of methods for obtaining, processing, and presenting information [11]. Meeting the consumer demand of users requires powerful and fast means of data collection, processing and storage. For the last five years, new information technologies that have been actively implementing by retail companies can be considered VR/AR, IOT, AI, and Big Data.

Instrumental solutions based on VR / AR technologies are used in various fields. The relative dynamic (due to the high cost) implementation of such technologies is explained by the advantages obtained: the speed of reproduction and modeling of objects; information completeness. Retail companies also use the technology. For example, in 2013 Google began testing a tool called "Google Glass" that tracked people's behavior and psychological response to purchases. Based on physiological indicators, the factors influencing the choice of the buyer were determined and a customized model of buying a specific consumer was developed. Walking through virtual stores (MYER, IKEA) and simulating a state of presence become commonplace.

The market for VR and AR technologies is constantly growing: so according to researchers, by 2023 its volume will increase by 9 times [5]. The largest contribution to the development of technology is made by the service sector, the size of their investment reaches $\$ 1.6$ billion. In the second place there are investments of retail companies [19]. It 
is obvious that this demand in these two sectors is due to the specifics of consumers ' interaction with the seller and the object of the transaction. These technologies are focused on solving consumer problems and allow to increase the involvement and assimilation of information by users (consumers or employees), as well as quickly track data (for example, using VR/AR technologies, you can track the number of products in stock).

The second most popular distribution is development based on IOT (Internet of things) technology. Typically, an IOT is a computer network that can collect, process, and transmit data to other devices. In general, IoT technology allows you to automate processes and reduce costs, notify about discounts and promotions, depending on the customer's location, automate the purchase process, and in the pandemic, this is especially important, because it reduces the number of contacts between people.

According to estimates of the international consulting company McKinsey, the impact of IoT devices on the economy may increase by 2025 and reach from 410 billion to 1.2 trillion dollars [12].

Tool solutions based on artificial intelligence (AI) provide the ability of the system to be similar to a person. According to IMB, by 2021 , more than $70 \%$ of retail will use intelligent automation tools [6]. Artificial intelligence can be used to improve product delivery processes, optimize, forecast demand, create more accurate marketing campaigns. Companies invest resources to maintain order on the shelves to reduce these costs some companies use robots to keep order on the shelves.

Tools based on Big data technologies allow companies to increase their efficiency by making decisions based on the analysis of patterns in the collected data. It is already common to make decisions based on the analysis of such data (forecasting demand, determining product placement, ensuring product flow routing, speeding up delivery, optimizing logistics, and navigation).

The company's analysts analyze the available information about purchases made, about the market as a whole, so they can build the company's future strategy, anticipate trends and unexpected situations.

The review of modern technologies (Table 1) in the retail industry showed that the market is actively implementing new technologies, developing interaction with IT companies.

Table 1. Comparative analysis of the dominant retail information technologies

\begin{tabular}{|c|c|c|c|c|}
\hline Factor & AR/VR & IOT & $\begin{array}{c}\text { Artificial } \\
\text { Intelligence }\end{array}$ & Big Data \\
\hline $\begin{array}{c}\text { Advantag } \\
\text { es }\end{array}$ & $\begin{array}{l}\text { Increases the } \\
\text { attractiveness of } \\
\text { the brand; } \\
\text { Customer } \\
\text { analytics; } \\
\text { Employee } \\
\text { training; } \\
\text { Personalization; } \\
\text { Growth of } \\
\text { engagement }\end{array}$ & $\begin{array}{l}\text { Supply chain } \\
\text { management; } \\
\text { Cost } \\
\text { optimization; } \\
\text { Improved } \\
\text { customer } \\
\text { service; Sales } \\
\text { automation; } \\
\text { A wide range of } \\
\text { applications }\end{array}$ & $\begin{array}{l}\text { Reduce costs; } \\
\text { Accelerate } \\
\text { processes; } \\
\text { Make effective } \\
\text { decisions; } 24 / 7 \\
\text { Work; Improve } \\
\text { the service } \\
\quad \text { quality }\end{array}$ & $\begin{array}{c}\text { Up-to-date } \\
\text { information about the } \\
\text { state of the retail } \\
\text { network; } \\
\text { Getting forecasts of } \\
\text { demand and sales, } \\
\text { Analysis of } \\
\text { marketing events; } \\
\text { Personalization of } \\
\text { offers; Geo-analytics }\end{array}$ \\
\hline
\end{tabular}




\begin{tabular}{|c|c|c|c|c|}
\hline $\begin{array}{c}\text { Limitation } \\
\mathrm{s}\end{array}$ & $\begin{array}{c}\text { High cost of } \\
\text { implementation } \\
\text { Technology } \\
\text { quality } \\
\text { Unknown effect } \\
\text { on the human } \\
\text { psyche }\end{array}$ & $\begin{array}{c}\text { High } \\
\text { implementation } \\
\text { cost; Data } \\
\text { security; } \\
\text { No unified } \\
\text { standards; } \\
\text { Reduction of } \\
\text { workers }\end{array}$ & $\begin{array}{c}\text { High cost of } \\
\text { implementation } \\
\text { and operation; } \\
\text { Reduction of } \\
\text { jobs; Security } \\
\text { of personal } \\
\text { data }\end{array}$ & $\begin{array}{c}\text { Specialized } \\
\text { personnel are } \\
\text { required; it is not } \\
\text { known what factors } \\
\text { affect these or other } \\
\text { processes; } \\
\text { It is quite expensive } \\
\text { to store all the data }\end{array}$ \\
\hline $\begin{array}{c}\text { Popularity } \\
\text { frequenc } \\
\text { y of use) }\end{array}$ & $\begin{array}{c}\text { Popular among } \\
\text { retailers }\end{array}$ & Gain popularity & $\begin{array}{c}\text { It is in demand } \\
\text { in clothing } \\
\text { stores. }\end{array}$ & $\begin{array}{c}\text { The most popular } \\
\text { technology by } \\
\text { frequency of use and } \\
\text { implementation }\end{array}$ \\
\hline
\end{tabular}

Comparative analysis has shown that each technology has its own purpose and its own set of advantages and disadvantages. So, it is impossible to talk about the significant advantages of a particular technology.

To assess the prevalence of the presented technologies in the activities of retail companies there were used reports and analysis of companies' strategic intentions. Large Russian retailers using modern information technology. For example, FMCG retailers cooperate with retailers in other areas. So in February 2020, the companies "X5 Retail Group, Beeline, "M.Video-Eldorado" and "Hoff" united in search of innovations to solve urgent business problems. There is evidence that X5 tested VR for staff training and received a $4 \%$ increase in service level and 8\% increase in productivity (2018) [5].

Lenta has implemented a system for analyzing information about the full cycle of activities [14]. Previously, all data was collected manually and took a long time to process. Implemented technological solutions based on information technology allow you to quickly obtain information and analyze a large number of disparate factors that affect sales. Chain stores "Karusel" implemented a system of "smart" planograms, which automatically determines the best shelf space for each product. The technology is based on an algorithm that simultaneously takes into account the influence of many parameters. The technology allowed to increase sales of certain categories of products, reduce the time of product placement, and generally reduce operating expenses (2017). "Magnit" company has automated logistics processes as much as possible. So, the company applies the system of the ADR (Automatic Delivery Rewards), Automatic Forecasting, Automatic Placement, remote acceptance and verification of goods.

Thus, large retail companies actively use and implement information technologies in their business processes. Companies combine methods of competitive struggle. One of the competition tools is such technologies as VR/AR, IOT, AI, and Big Data. Despite the advantages and disadvantages of each technology, Russian retailers are actively implementing modern technologies in the company's processes. Since these technologies allow you to optimize business processes and contribute to the growth of key business indicators and, as a result, competitive advantages in the market.

\section{Assessment of the growth dynamics of business indicators due to the introduction of information technologies. Research result}


A research question under study is: the impact of information technology implementation on the company's competitive advantages in the market. Enterprises operating in the network retail industry "X5 Retail Group", "Magnit" were selected as the object under observation. The choice of companies is determined by the steady growth of the market share. This growth may be due, among other things, to the active use of information technologies. Data collection for confirmation/refutation of a research question is organized in three stages. The first quantitative stage contains information from open sources about information technologies implemented by companies during 2017-2018 (Table 2).

Table 2. Modern digital technologies introduced in companies in 2017-2018.

\begin{tabular}{|c|c|c|c|}
\hline \multicolumn{2}{|c|}{ X5 Retail Group } & \multicolumn{2}{c|}{ Magnit } \\
\hline Year & Implemented technology & Year & Implemented technology \\
\hline \multirow{4}{*}{2017} & $\begin{array}{c}\text { Self-Scan System } \\
\text { Smart Data X5 } \\
\text { Perekrestok-online } \\
\text { Robot Vera }\end{array}$ & 2017 & $\begin{array}{c}\text { Pick-by-Voice } \\
\text { The system integration of MRO } \\
\text { Machine Learning }\end{array}$ \\
\hline \multirow{2}{*}{2018} & $\begin{array}{c}\text { VR technologies for staff training } \\
\text { Navigating the store } \\
\text { Automatic creation of planograms } \\
\text { Sensors to control energy } \\
\text { consumption }\end{array}$ & 2018 & $\begin{array}{c}\text { Automation of logistics } \\
\text { Electronic contracts with suppliers }\end{array}$ \\
\hline
\end{tabular}

A number of technologies implemented in companies' activities coincide. This situation also makes it possible to compare the impact of information technology on the growth rate of key business indicators. Therefore, this study analyzes the impact of different technologies, whereas the identical technologies are used for a comparative assessment of the power of influence.

At the second quantitative stage the analysis of annual reports of "X5 Retail Group" and "Magnit" companies was carried out for 2016-2019. It is assumed that the gain in competition can be described by a set of parameters that can be measured using secondary indicators, which can probably include indicators of business performance, such as profit, number of sales, etc.

To assess the level of company competition in the market, a set of indicators has been formed that may reflect competitive advantages. According to the idea of the study, it is necessary to conduct a comparative analysis of indicators before and after the introduction of information technologies. The review of the implemented technologies was made for 2017-2018. Therefore, the period before is considered the time period of 2016-2017; the period after 2018-2019. We assume that, all other things being equal, the introduction of information technologies (Table 2) in the company's activities affects the improvement of business indicators and, as a result, competitive advantages.

In general, according to the comparative data, the growth rate is fixed for all indicators (Table 3). However, companies that occupy almost equal market shares record different growth rates (X5 Retail Group - 48\%, Magnit - 15\% in 2016/2018, and 33.98\%, and $19.71 \%$ in $2017 / 2019$ respectively).

Table 3. Comparison of business indicators for 2016 / 2018. 


\begin{tabular}{|c|c|c|c|c|}
\hline & \multicolumn{2}{|c|}{$\mathbf{2 0 1 6 / 2 0 1 8}$} & \multicolumn{2}{c|}{ 2017 / 2019 } \\
\hline $\begin{array}{c}\text { Growth rate of } \\
\text { indicators, \% }\end{array}$ & $\begin{array}{c}\text { X5 Retail } \\
\text { Group }\end{array}$ & Magnit & X5 Retail Group & Magnit \\
\hline Revenue & 48.25 & 15.09 & 33.98 & 19.71 \\
\hline Gross profit & 48.00 & 0.30 & 37.77 & 7.77 \\
\hline Number of retail outlets & 57.08 & 30.87 & 34.45 & 26.76 \\
\hline Retail space & 50.26 & 26.78 & 32.12 & 25.77 \\
\hline The regions of presence & 3.22 & 1.56 & 3.17 & 4.69 \\
\hline $\begin{array}{c}\text { Number of employees } \\
\text { The cost of training } \\
\text { employees }\end{array}$ & 41.95 & 9.03 & 22.55 & 11.63 \\
\hline $\begin{array}{c}\text { Number of trained } \\
\text { employees }\end{array}$ & 78.13 & $\mathrm{n} / \mathrm{a}$ & 43.43 & $\mathrm{n} / \mathrm{a}$ \\
\hline \begin{tabular}{c} 
Number of visits \\
\hline
\end{tabular} & 53.36 & $\mathrm{n} / \mathrm{a}$ & 56.11 & $\mathrm{n} / \mathrm{a}$ \\
\hline
\end{tabular}

Internal organizational and managerial factors that influence how measurements are implemented might contribute to this. This allows us to conclude that the introduction of information technologies has a positive impact on the performance of companies, but the level of influence is determined not only by technology, but also by internal organizational and managerial factors. It is noted that other things being equal, the cost of training employees has increased, but this phenomenon cannot be considered negative. New technologies are characterized by different periods of adaptation of employees to new ways of performing operations. Therefore, to assess the impact of the factor, it is necessary to track the cost of training over a longer period. This position is confirmed by the multiplying value of the indicator "Number of employees who have completed training". The impact of technology on reducing the number of employees requires further study. Because during this period, the number of retail outlets significantly increased. The introduction of information technology has increased the number of visits to retail outlets by more than 2 times, including through online sales.

Thus, the analysis of secondary data shows a positive relationship between the implementation of information technologies and the business results of the organization.

For more detailed testing of the research question, i.e. the impact of the introduction of information technologies on the company's competitive advantages in the market, an interview was conducted with a line manager of the Nielsen department for working with retailers.

The structure of the interview included several sections. The first section allows to get an expert opinion on a set of current information technologies implemented in the activities of companies in the retail sector. According to the expert, the most popular tools are those ones which are aimed at increasing the customer flow, the average receipt, and the growth of loyalty to the network's brand. These technologies are implemented mainly in the internal processes of the company. For example, electronic systems are being introduced to optimize distribution centres. The cost of manual operations is reduced, and as a result, the business process is carried out in a shorter time and using fewer resources. 
The second section of the expert interview is aimed at evaluating the advantages that the company receives. The key advantage, according to the expert, is the optimization of business processes, which allows you to reduce the number of employees or reorient them; improve the quality of service and keep customer traffic. Also a significant advantage is the rapid adjustment to changes in the external environment. All this helps to maintain sales volumes even in conditions of changing external environment and emergency situations. For example, the companies under analysis in this paper in the current pandemic managed to cope with the increased flow of online customer orders due to the operational readiness of the business and the early gradual introduction of appropriate technologies.

According to the expert, any digitalization and implementation of technologies in the retail business impact on business. Therefore, implementation is unambiguous and inevitable. The only question is speed: those companies that started implementing earlier will get more advantages in the current period.

In the final section it was offered to confirm or deny the data obtained on the rate of technologies influence on the performance of companies. The stronger impact that we have identified in our analysis is due to the fact that X5 Retail Group started upgrading retail outlets 1.5 years earlier than Magnit. The company was the first to change the concept of attractiveness for the buyer, expanded many categories of products. "Pyaterochka", while maintaining a low price level, became much faster that convenience shop, which gave consumers both price and quality. "Magnit" has developed much slower in this direction (it is only going to finish extensive growth and work on quality). Therefore, the stronger impact of technologies on business indicators is explained by the start and intensity of their implementation.

Thus, modern information technologies affect the business performance of companies, which in turn are the basis of competitive advantages of companies in the market. There is a positive relationship between the introduction of information technologies and the business results of the organization. Large companies have been implementing information technologies in the company's business processes for several years to improve the performance of indicators.

\section{Conclusion}

The retail market is actively using new sales channels, which lead to an annual increase in the market share of the market's leading chain retailers. The overall development is influenced by trends in consumer demand and the speed of companies' response to them. Restrictions on the speed of development of the domestic market in comparison with foreign ones are the gradual decline in income of the population, as well as the heterogeneity of the Russian market.

For development, companies need to combine different methods of competition to achieve their strategic goals. Information technologies such as VR/AR, IOT, AI, and Big Data contribute to increasing competitive advantages in the retail sector. All technologies have advantages and disadvantages. Despite the disadvantages, Russian retailers actively use and optimize their business processes using these tools. The study reveals the relationship between the implemented information technologies and the business results of companies. 
In the future, new information technologies will appear in the retail market, which will also change the business processes of companies and affect the results of companies' activities.

\section{References}

1. W.N. Ander, N.Z. Stern, Winning at retail: developing a sustained model for retail success (United States: John Wiley \& Sons, 2010)

2. N. Ambady, M.A. Krabbenhoft, D. Hogan, The 30-sec sale: using thin slice judgments to evaluate sales effectiveness, J. Consum. Psychol. 16(1), 4-13 (2006)

3. A.S. Al-Adwan, M.A. Al-Horani, Boosting customer e-loyalty: an extended scale of online service quality, Information, 10, 380 (2019)

https://doi.org/10.3390/info10120380

4. B. Burroughs, W.J. Burroughs, Digital logistics: Enchantment in distribution channels, Technology in Society, 62 (2020)

5. M. Cortinas, R. Chocarro, M. Elorz, Omni-channel users and omni-channel customers: a segmentation analysis using distribution services, Spanish Journal of Marketing - ESIC, 23(3), 415-436 (2019)

6. D. Gilbert, Retail marketing management (United Kingdom: Pearson Education Limited, 2018)

7. Forecast augmented (AR) and virtual reality (VR) market size worldwide from 2016 to 2020, Statista URL: https://www.statista.com/statistics/591181/globalaugmented-virtual-reality-market-size/ (15.04.2020).

8. FMCG trends in Russia, GFK URL: https://www.gfk.com/ru/press/fmcg-trendy-vrossii (20.03.2020).

9. M. Jocevsk, A. Ghezz, N. Arvidsson, Exploring the growth challenge of mobile payment platforms: A business model perspective, Electron. Commer. R. A., 40 (2020)

10. J. Kang, M. Majer, H-J. Kim, Empirical study of onichannel purchasing pattern with real customer data from health and lifestyle company, Sustainability, 11, 7185 (2019)

11. M. Krafft, M.K. Mantrala, Retailing in the 21st Century: Current and Future Trends ( Germany: Springer Science \& Business Media, 2009)

12. S. Quach, P. Thaichon, C. Hewege, Triadic relationship between customers, service providers and government in a highly regulated industry, Journal of Retailing and Consumer Services, 55, 102-148 (2020)

13. M. Shi, J. Zhou and Z. Jiang, Consumer heterogeneity and online vs. offline retail spatial competition Front. Bus. Res. China Vol 13 No 10) (2019)

14. B. Stockinger, Broadband internet availability and establishments' employment growth in Germany: evidence from instrumental variables estimations, Labour Market Res, 53, 7 (2019) 
15. Stone K E 1995 Competing with the retail giants: how to survive in the new retail landscape (United States: John Wiley \& Sons)

16. M. Stoklasa, Influence of technology on regional brands in Czechia, Engineering Management in Production and Services, 11, 4 (2019) https://doi.org/10.2478/emj2019-0036

17. J.Z. Zhang, G. F. Watson, Marketing ecosystem: An outside-in view for sustainable advantage, Industrial Marketing Management, 88, 287-304 (2020)

18. W.N. Wassouf, R. Alkhatib, K. Salloum, Predictive analytics using big data for increased customer loyalty: Syriatel Telecom Company case study, Big Data, 7 (2020) https://doi.org/10.1186/s40537-020-00290-0

19. J.R. White, K.D. Gray, Shopping centers and other retail properties: investment, development, financing, and management (United States: John Wiley \& Sons, 1996) 